\title{
Why Walking the Common is more than a Walk in the Park
}

\author{
Nike Romano ${ }^{1}$, Veronica Mitchell², and Vivienne Bozalek² \\ ${ }^{1}$ Cape Peninsula University of Technology, Cape Town South Africa and ${ }^{2}$ University of the \\ Western Cape, Cape Town South Africa
}

\begin{abstract}
For the past few years, as concerned academics and educators in South African higher education, we have come together to meet/think/drink coffee/eat/discuss our research and teaching practices in a coffee shop that overlooks the Rondebosch Common, a public space and national heritage site. The Common invited us to take our thoughts for a walk and we embarked on numerous walking encounters that affected and troubled us in many ways. Our walks became research-creation events that surfaced the implicatedness of our white settler privilege. As we grappled with the complexities and ambivalences grounded in our relationality with this contested site, we were prompted to explore hauntology as a theoretical orientation for our pedagogical practices. Walking with/through the demarcated land that is surrounded by privilege in terms of buildings, services and residences enacted and materialised entanglements of the past/present/future histories. We felt an exchange of affect between those present, the ghosts of colonial and apartheid histories, and the implications for our ongoing teaching. Following Haraway's (2016) 'staying with the trouble' and Tsing et al.'s (2017) 'how to live on a damaged planet', the relationships between human and non-human continue to haunt us, as we grapple with the im/possibility of finding common ground in a country devastated by colonial and apartheid violences.
\end{abstract}

\section{Keywords}

Research-creation; walking methodology; hauntology; white privilege; the Common 
For the past few years, as concerned academics in South African higher education, we have come together to meet/think/eat/drink coffee and discuss our research in a cafe that overlooks the Rondebosch Common, a haunted national heritage site that is an open public space spanning 40 hectares. The Common carries the wounds of systematic dispossession of land and exploitation of indigenous populations in South Africa that began with Dutch and British colonisation from the seventeenth century onwards. The Natives Land Act of 1913 formalised the division of land into areas called 'reserves', that restricted Africans who comprised $70 \%$ of the population to owning only $8 \%$ of the land.

In 1948, the newly elected Nationalist party government implemented the apartheid ${ }^{\mathrm{i}}$ system through a series of racialised policies that comprised political, social and economic exclusions for all who were not officially categorised as white. In the apartheid era, health, education, housing and social welfare systems were designed to meet the needs of the white minority in South Africa. Two significant legal instruments of apartheid were the Group Areas Act No 40 of $1950^{\mathrm{ii}}$ and the Reservation of Separate Amenities Act No 49 of 1953. ${ }^{\text {iii }}$ The multiple legacies of these Acts continue to haunt the country from the time of democracy, established in 1994, to the present. These legacies re/turn in the materialised sedimentation of the physical layout of suburbs such as Rondebosch and the built structures that include privileged educational and state health institutions such as the Red Cross War Memorial Children's Hospital (the largest paediatric care centre in Africa) as well as wealthy, mainly white-owned homes that flank the Common.

The Common is home to about 230 endangered species including the Cape Flats sand fynbos $^{\text {iv }}$ that face an ongoing threat of extinction. Ecological publics ${ }^{v}$ of snakes and small creatures including domestic animals, move in and through the 'veld,' a local term for indigenous grassland, with visits from forty species of birds. ${ }^{\text {vi }}$ The sun's rays illuminate and reflect/refract a multiplicity of colours and shapes in the early mornings. We are mindful, however, of the 'god trick' as an all-seeing gaze (Haraway, 1988), signifying "the un-marked positions of Man and White" (p. 581) that obliterates and obfuscates the multiple becomings-with the Common and the hauntological absent-presences of its ghostly publics (Barad, 2017).

The Common invited us to walk/talk/think together with (in)tension (Springgay \& Truman, 2018a; 2018b) and to draw on Barad's (2017) hauntology as a theoretical orientation to explore the ghostly publics connected with and through the past/present/future of this site. As white settlers, our walking encounters a/effected and troubled us because of our implicatedness in the complexities and ambivalences grounded in this contested site.

We think-with the undercommons, a term coined by Harney and Moten (2013), to actively consider how our gathering and moving through the space of the Common brings together the physical and the virtual. As we intra-act with the problems and potentials emerging through our encounters, Manning (2016) reminds us that "it is in the midst of the field of relations, in the undercommons, that practices are at their most inventive, at their most intense" (p. 39). Our "thinking-in-movement" (Springgay \& Truman, 2018a, p. 204) began as an agitation in the speculative middle, "gnawing" (p. 206) and moving us to experimentally work through our concerns.

Our encounters are haunted and entangled with the ghosts of colonial land appropriation, the 1807 Dutch Military encampment, the 2001 rape of a 17 year old girl ${ }^{\text {vii }}$ walking home from a privileged school adjoining the Common, the 1950 Group Areas Act and the 2012 Occupy Rondebosch Common protests against crime and lack of affordable social housing in the city. We are further troubled by the deeper layers of hauntings in the geopolitics of past apartheid policies. The Cape Flats has become known as apartheid's dumping 
ground for displaced communities who were forcibly removed from newly proclaimed whites-only suburbs by the Group Areas Act. The ongoing threat of extinction of the Cape Flats sand fynbos is further exacerbated by the mushrooming of informal settlements being built by thousands of people, who continue to migrate from the poverty of rural areas to the metropolis of Cape Town, in search of improved livelihoods.

Thinking-walking-writing-talking-learning with the Common is troubling, unsettling, ambivalent, risky. The Common is a misnomer. It implies the innocence of a terra nullius (Barad, 2017; Springgay \& Truman, 2018a) and a benign and inclusive hospitality. The Common is constructed as a so-called open green space that is supposedly accessible to all. However, given the double-troubling of land appropriation through colonisation and the Group Areas Act, walking/thinking on this piece of land which is the Common, produces unsettling thoughts of our implicatedness as settler/interlopers, walking on stolen land. The Common becomes a geopolitical troubling force. It sits abruptly in the middle of a privileged white suburb, flanked by busy roads, disconnected from its environ. We are troubled and shamed by our white privileged positionality and unsettled in/by the Common space. At the same time, a gendered vulnerability and precarity haunts our walking/writing on the Common, in a country where extreme levels of gender-based violence are perpetrated (Jewkes et al., 2011).

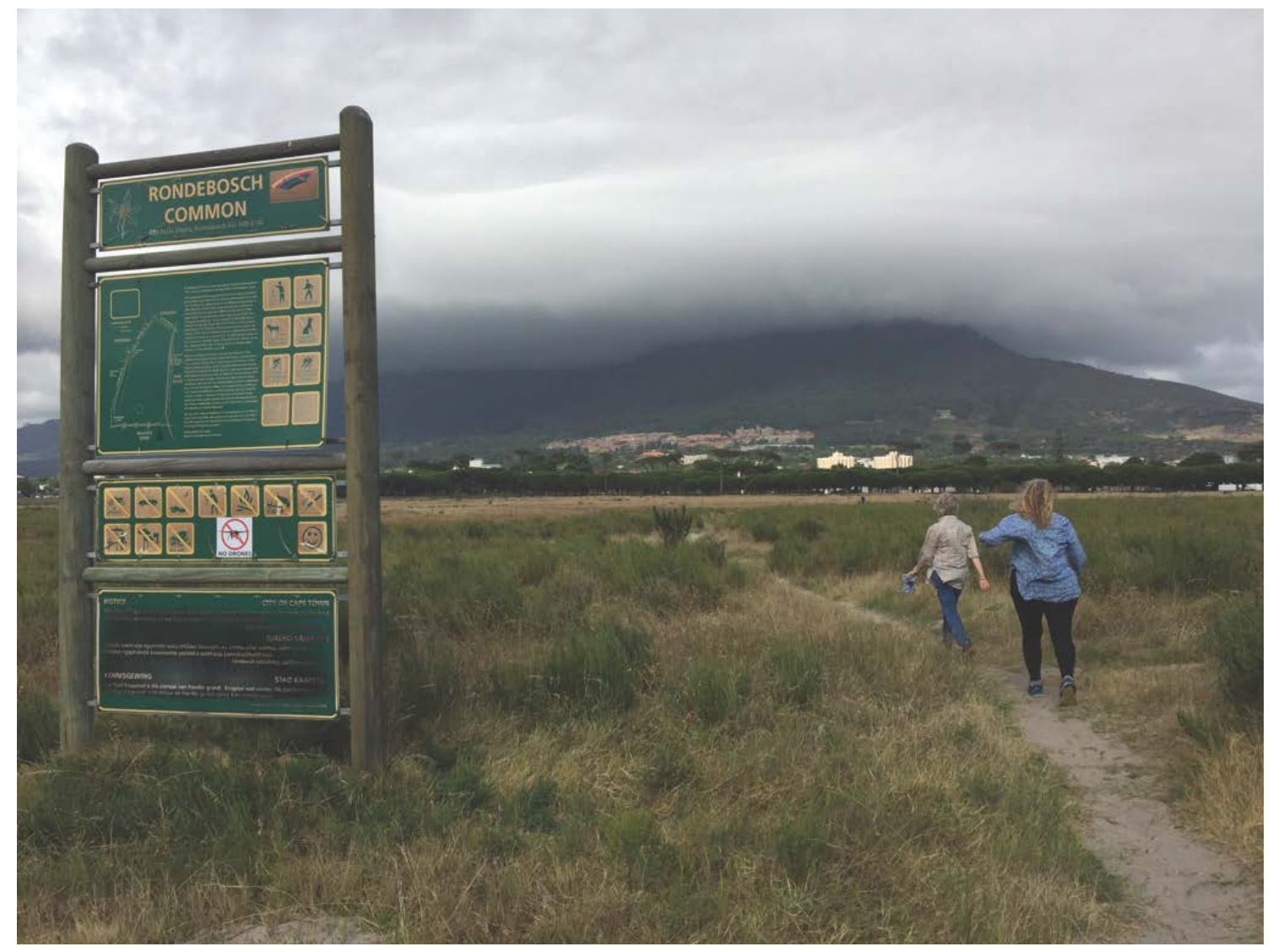

Figure 1: Becoming with the Common. Photo credit: Nike Romano.

Initially we walked tentatively, circling the Common on the tarred sidewalk frequented by walkers/runners/pedestrians, and later ventured into the middle where we hoped for some kind of clarity as to why this is such a troubling spacetimemattering (Barad, 2007). We found ourselves in a speculative middle, trying to embark on the unknown by moving away from 
conventional academic norms of regimenting and judging, we veered off the paths. Pulled by the trees and their shadows, we ruminated with the birds, grasses and ghostly publics where evidence of human activities were visible in the form of discarded yoghurt containers, packets and tissues. Haunted by the rape, we felt safer walking together as a collective human public in this space. The assumed freedom and privilege of walking as characterized by the dérive, is severely constrained in the South African context, where the starkness of some racialised, gendered, classed and differently-abled bodies become disposable in order for others to thrive (Springgay \& Truman, 2018a).

Our re/turning to walking on several occasions in/through the Common as intensive research-creation events, generated new affective connections to past and future hauntings. Our movements and immersion with space and matter shifted us from the equanimity of sitting with each other, writing and thinking in our meetings across from the Common, to becoming-with the Common, meeting the different troubles that matter, and facing those unsettling matters with the Common. Without the walks there could have been false closure. As Barad (2012) points out:

Thinking has never been a disembodied or uniquely human activity. Stepping into the void, opening to possibilities, straying, going out of bounds, off the beaten path-diverging and touching down again, swerving and returning, not as consecutive moves but as experiments in in/determinacy. (p. 208)

Following Haraway's (2016) 'staying with the trouble' and Tsing et al.'s (2017) 'how to live on a damaged planet,' these relationships, human and non-human, continue to haunt us, as we grapple with the im/possibility of finding common ground in a country devastated by colonial and apartheid violence. In terms of our implicatedness and what this means for ourselves as settlers and as educators in higher education, we continue to be troubled by our positions as non-indigenous theorists. Referring to Canadian-colonial occupation, Arthur and Jentink (2018) indicate how land troubles writing. For them, composting becomes a messy process in which knowledge can flow from land - bringing new sensibilities for thinking/learning/writing with land and non-human others.

Walking-writing intentionally activates a disjunctive synthesis. Walking-writing is a practice of muddling things, of making problems, and agitating thought. In the speculative middle one does not resolve or clarify an idea, rather walking complicates, stirs, and unsettles thought. In fact sometimes nothing comes out of a speculative middle. Sometimes it is about failure and a letting go. (Springgay \& Truman, 2018a, p. 134)

Rather than seeking resolution through our unsettled/unsettling walks in the park, we 'become' with our settler/unsettling and re/turn to the paradoxical muddling-middle of the disjunctive synthesis. In this regard, Freccero's (2006) proposition that the way in which spectral being and doing opens "us up to porous, permeable pasts and futures - suffused with affect and its ethical implications" is what enables us both "to mourn and also to hope" (p. 69). Walking the Common is more than a walk in the park. 


\section{References}

Arthur, M. \& Jentink, R. (2018). Composting settler nationalisms. Capacious: Journal for Emerging Affect Inquiry, 1(3), 152-182. https://doi.org/10.22387/CAP2018.20

Barad, K. (2007). Meeting the universe halfway: Quantum physics and the entanglement of matter and meaning. Durham, NC: Duke University Press.

Barad, K. (2012). On touching - The inhuman that therefore I am. differences: A Journal of Feminist Cultural Studies, 23(3), 206-223. doi:10.1215/10407391

Barad, K. (2017). Troubling time/s and ecologies of nothingness: Re-turning, remembering, and facing the incalculable. Posthuman Temporalities, 92, 56-86. doi:10.3898/NEWF:92.05.2017

Bennett, J. (2010). Vibrant matter: A political ecology of things. Durham, NC: Duke University Press.

Freccero, C. (2006). Queer/Early/Modern. Durham and London: Duke University Press.

Haraway, D. (1998). Situated knowledges: The science question in feminism and the privilege of partial perspective. Feminist Studies, 14(3), 575-599.

Haraway, D. (2016). Staying with the trouble: Making kin in the Chthulucene. Durham, NC: Duke University Press.

Harney, S., \& Moten, F. (2013). The undercommons: Fugitive planning \& Black Study. Wivenhoe, NY: Minor Compositions.

Jewkes, R., Sikweyiya, Y., Morrell, R. \& Dunkle, K. (2011). Gender inequitable masculinity and sexual entitlement in rape perpetration South Africa: Findings of a cross-sectional study. PLoS ONE 6, 12, e29590. https://doi.org/10.1371/journal.pone.0029590

Manning, E. (2016). The minor gesture. Durham, NC: Duke University Press.

Springgay, S., \& Truman, S. (2018a). Walking methodologies in a more-than-human world: WalkingLab. London, UK: Routledge.

Springgay, S., \& Truman, S. (2018b). On the need for methods beyond proceduralism: Speculative middles, (In)tensions, and response-ability in research, Qualitative Inquiry, 24(3), 203-214. https://doi.org/10.1177\%2F1077800417704464

Tsing, A., Swanson, H., Gan, E., \& Bubandt, N. (Eds.) (2017). Arts of living on a damaged planet: Ghosts of the anthropocene. Minneapolis, MN: University of Minnesota Press.

Nike Romano teaches History and Theory of Design at the Cape Peninsula University of Technology. Her research focuses on developing art history pedagogical strategies that respond to the contingencies arising out the call to decolonise South African universities. Nike is a $\mathrm{PhD}$ candidate at the University of the Western Cape.

Veronica Mitchell is a PhD candidate at the University of the Western Cape and a human rights facilitator in the Department of Obstetrics and Gynaecology, University of Cape Town. Her publications include a research blog, authored websites, book chapters and journal papers on aspects of new materialism and posthumanism. 
Vivienne Bozalek is Professor of Social Work and Director of Teaching and Learning at the University of the Western Cape and has a PhD from Utrecht University. Her research interests include the ethics of care and social justice, posthumanism and feminist new materialisms, pedagogies in higher education, postqualitative and participatory methodologies.

\footnotetext{
i Apartheid is an Afrikaans word meaning apartness or separation.

ii The Group Areas Act No. 41 of 1950 assigned racial groups to different residential and business sections in urban areas in a system of urban apartheid. Buttressed by apartheid legislation, the Nationalist party government was responsible for approximately 3,5 million people being forcibly removed from their land and hundreds of thousands from their houses.

iii The Reservation of Separate Amenities Act No 49 of 1953 purposefully separated all public amenities including schools, trains, buses, churches, restaurants, hotels, parks, beaches, bars, toilets etc. The act prohibited those who were not assigned to the white group from using these public amenities.

iv Fynbos is a small belt of indigenous natural shrubland located in the Western Cape and Eastern Cape provinces of South Africa.

" Publics are "groups of bodies with the capacity to affect and be affected" (Bennett, 2010, p. 101)

vi See Facebook page of Friends of the Rondebosch Common for further details.

vii While the rape of a the school girl, who was white, received a lot of media coverage at the time as it should have, we were also haunted by the countless other rapes that occur on a daily basis in South Africa that never get reported on.
} 